\title{
Leadership styles and managerial culture at industrial enterprises with different modernization and innovation processes
}

\author{
Sergei Glukhov, ${ }^{1, *}$, Petr Glukhov ${ }^{2, *}$ \\ ${ }^{1}$ South Ural State University, Logistics, Economics and Management in Transport, Supply and Distribution Department of Higher \\ School of Economics and Management, Chelyabinsk, Russia \\ ${ }^{2}$ South Ural State University, Laboratory «Psychology and Psychophysiology of Stress Resistance and Creativity» of Higher School \\ of Medicine and Biology, Chelyabinsk, Russia
}

\begin{abstract}
The article presents the results of an empirical research into the transformational leadership and managerial culture at industrial enterprises with different modernization and innovation processes. The authors suggest the criteria for differentiation of options of making changes at the industrial companies: the attitude to their own research base, the focus on introduction of innovations, the investment potential for the introduction of innovations, contacts with research and educational agencies, presence of institutional innovation structures in the structure. It was found out that the managerial profile of an industrial enterprise, focused on innovation activities, involves the index of transformational leadership and the managerial culture with a subject-oriented management, i.e. democratic, which is manifested in the commitment to the group decision making process; humanizing, which is manifested in the attitude towards the employees as being independently valuable regardless the context of achieving organizational results; and innovative, which is manifested in the constant quest for changes.
\end{abstract}

\section{Introduction}

Quality and speed of introduction of changes at industrial enterprises determine their adaptability to changing market conditions and, eventually, affect their competitiveness. To a large extent, effectiveness of introduction of changes depends on the characteristics of personnel management. Tools for assessment of human capital of the managers of industrial enterprises become highly sought in addressing the problem of introduction of changes.

Additionally, the importance of the task is related to the cultural chasms and psychological barriers towards introduction of changes, formed as a result of traditionally extensive development of the Russian economy, easier access to resources, and fear of changes $[1,2]$.

Thus, it would be logical to focus the research on the intersection of such sciences as Economics, Management and Psychology, on the economic and psychological aspects of Management - on assessment of a relationship between the individuality of a manager and the level of managerial culture at an industrial enterprise. It will let us identify and describe a profile of a manager who can effectively manage both the introduction of external innovations (modernization process), and the introduction of innovations created within the enterprise (innovation process). This approach can be an effective tool for human resources management and it can be used in the system of evaluation and training of personnel at industrial enterprises.

\section{Topicality. Scholarly Importantce of the Issue}

Contemporary study of personality and managerial culture of an industrial organization in the context of modernization and innovation processes is conducted both by foreign and Russian authors.

Some authors studied leadership position of the managers during introduction of changes at an enterprise. For example, Alain Vas studied leadership through management in complex, vague and ambiguous conditions, due to a specific set of such characteristics as commitment to support organizational changes, courage, belief in the staff's ability to take over responsibility [3]. Richard L. Daft analyzed leader's strategy of changes in management through the individual scenarios of managers' activities. He singled out a strategy of "creative self-expression", which implies a non-standard behaviour, creative actions, which approve new norms and values; a strategy of "alliances" which consists in formation of a group of allies of innovations around an innovative leader, and a number of other strategies [4]. B. Bass described and empirically identified a transformational style of leadership, aimed to initiate in the employees an aspiration to achieve higher

*orresponding author: glukhovsv@susu.ru 
organizational goals. A manager with such style instigates the staff to move to a higher level of motivation, he raises their ethical expectations. B. Bass singled out a specific character of the influence on the part of a manager with a high level of transformational leadership: the staff gets motivated and gains sight of the set goals; their self-actualization needs are satisfied; their interests expand beyond their personal fulfillment (a turn to organizational actualization) $[5,6]$.

V.G. Griazeva-Dobshinskaia suggested using a system approach to study innovative leadership of managers. It is the most sophisticated and modern approach, which takes into account manifestations of behaviour of the managers at different levels of managerial communication [7-9]. At the same time, the majority of the above listed studies of leadership in the context of changes is based on the well-developed theoretical concepts and on high expertise of its authors. A comparison of the socio-economic characteristics of industrial enterprises with a distinct particular management attitude, described in the theory, remains central for identification of a profile of a manager who can effectively manage introduction of changes.

Research of the managerial culture during introduction of changes. R. Florida described the specificity of a social environment which favours selfactualization of creative subjects and suggested a three " $\mathrm{T}$ " approach (technology, talent and tolerance) [10]. He found out that creative staff, contributing to the innovative development of enterprises, accumulates in spaces characterized by a high degree of tolerance (acceptance of diversity) and technology (acceptance of complexity and novelty).

Arie de Geus described conditions of a managerial environment in which adaptation occurs efficiently. Such conditions include tolerance for alternative behaviour and, as a consequence, decentralization, high cohesion and identity of personnel, enabling synergetic behaviour, sensitivity to the environment, which allows to accurately assess the events taking place inside and outside [11]. Iu.D. Krasovsky suggested paradigms of managerial culture, which can promote and block circulation of information and display of initiative [1214].

In order to study the personal profile of a manager and the managerial culture of an industrial enterprise under conditions of constant changes, we chose a concept of the transformational style of leadership, suggested by B. Bass in his works [5, 6], proved to be efficient in foreign studies, and a concept by Iu.D. Krasovsky, which is the most easily diagnosed and reflects the specifics of the Russian management culture [12-14]. An explorative framework was developed within these concepts in order to identify individual characteristics of the manager and of the administrative culture of an industrial company.

Accordingly, the aim of our research is to identify a personal profile of a manager who can effectively manage both the introduction of external innovations (modernization processes) and the introduction of innovations created within the enterprise (innovation processes), and it will be formed within the framework of the indicators suggested in these theoretical concepts.

\section{Statement of the Aim}

We set out the following tasks in order to achieve the aim of this article.

The first task is to differentiate the specifics of the introduction of changes at the industrial enterprises, whose managers participated in the study.

The second task is to study the relationship between leadership styles of the managers and the formed managerial culture at the industrial enterprises.

The third task is to draw up personal profiles of the managers who effectively manage the processes of modernization and innovation at the industrial enterprises.

\section{The Oretical Part}

B.M. Bass and his co-author B.J. Avolio defined transformational leadership as a new type of leadership and suggested understanding of transactional leadership as a leadership of the old school, based on interaction. They analyzed transformational and transactional leadership in a unified complex, which let them develop a model for their description [5, 15-17].

In our study, we are going to focus only on the description of transformational leadership (TL). There are four elements of transformational leadership.

The first one is idealized influence (II). The leaders with this ability give their subordinates a sense of purpose, they foresee the future, and set up new high standards. The transformational leaders suggest bright and meaningful images of the joint future. Ultimately, the employees feel that they take part in reaching a common goal, they feel concurrence of the objectives and values of organizational behaviour.

The second one is inspirational motivation (IM). The transformational leaders provide inspiration, high expectations, they inspire pride in the employees. They emphasize motivational managerial manifestations as much as possible. The atmosphere of openness and trust is important for those employees who generate new and creative ideas, and therefore the function of control, which is of top-priority during the stabilizing stages of development of the company, becomes irrelevant in times of changes.

The third element is intellectual stimulation (IS). The managers who possess this ability, help their employees to be more creative and innovative, they encourage the creation of new modes of action, and stimulate emergence of new ideas. They create a space for growth through open communication, through support for innovative ideas, and respect for those who suggest them.

The fourth element is individualized consideration (IC). The managers, leaders, who transform reality, communicate on a personal level, they consider each employee as an individual, give them the tasks which would contribute to their personal growth. Such 
approach allows them to build up a successful communication with the most creative and non-standard employees, taking into account their differences and peculiarities.

J. Burns described the leaders transforming reality as those who provoke the followers to go beyond their own interests and, thus, beyond their self-actualization. This type of leadership is considered as the highest level of leadership, when the leader expands the interests of the subordinates, when s/he generates awareness and acceptance of the goals and objectives of the group in them, when $s /$ he awakens in them a desire to look beyond their own interests for the good of the whole group [18].

Thus, the general formula of the integrative index of transformational leadership of the managers, taking into account the proportion of indicators (determined by the number of the questions in the test), is as follows:

$$
T L=\left(I I^{*} 8\right)+\left(I M^{*} 4\right)+\left(I S^{*} 4\right)+\left(I C^{*} 4\right),
$$

where TL stands for the integrative index of transformational leadership of the managers; II stands for idealized influence; IM stands for inspirational motivation; IS stands for intellectual stimulation; IC stands for individualized consideration.

Personal fulfillment of a leader is possible if a corresponding managerial culture is present at the enterprise. Iu.D. Krasovsky identifies the following parameters for the analysis of management culture, aimed precisely to perform analysis in the context of introduction of changes at the company: "openness" or "closeness" of the managerial culture, an emphasis on strength or flexibility of authority, a focus on business or personal communications, domination of fragmented individualistic or integrative group processes [12-14].

"Openness" of the organizational culture of a company is characterized, in the first place, by freedom of opinion exchange, an advanced communication system, completeness of information about solvability of management problems at employees' disposal, understanding of interdependence of everyone in the company, organizational clarity and transparency of business relations, solution of the "joint" problems of different departments, freedom of maneuver for employees with authority and rights, their inclusion into direct discussions and solution of the most important management issues.

"Closeness" of the organizational culture of a company is a directly opposite socio-cultural situation when a free exchange of opinions is hindered, communication systems are limited, the channels of information are blocked and narrowed, the interdependence of employees and departments is difficult to understand, when one person solves his or her own problems and does not worry about how this decision will affect the others, when the most important problems are solved privately, and the staff is caught in the need of execution of the managerial decisions taken. If such organizational culture exists and expands in the company, it means that the employees are being increasingly alienated from the business organization, and they conceive and evaluate their position as unsatisfactory.

Iu. D. Krasovsky suggests to conduct the analysis of managerial culture through more detailed categories, including administrative orientations of managers and, therefore, suggests an exploratory technique for managerial culture called "KRAB" [12-14].

The built-in model of this technique consists of two polar groups of managerial orientations: object and subject orientations. Object-oriented management can be converted to one-sided ways of "top-down" influence: a) autocratic, when the employees are subject to the power (the will) of the head; b) technocratic, when the employees are subject to the production process; c) bureaucratic, when the employees obey the organizational order, sometimes to the detriment of the business.

Subject-oriented management can be: a) democratic, when the head constantly takes into account the opinion of the workers during the adjustment of the workflow management; b) humanizing, when the head treats the workers with respect for their human dignity; c) innovative, when the head organizes introduction of initiative suggestions by giving the employees freedom of creativity.

The subject managerial orientations correspond to manifestations of transformational leadership, that is why our empirical research has been focused on them.

\section{Results of the Empirical Research}

Socio-economic characteristics of the three selected industrial enterprises of the Ural Federal District of the Russian Federation were analyzed in order to complete the first task of the empirical research.

Characteristic of the industrial enterprise No. 1.

The main production assets of the enterprise No. 1 have not been modernized, in large part, for a long period of time and can be included in the category of the off-market equipment. Currently, most competitive businesses use more modern compatibles, which allow them to gain a competitive advantage at the stage of production.

The company produces products of lower and middle-price segment. This situation can be explained by the level of technological development of the enterprise, which does not allow the company to produce products of a higher level.

Technical re-equipment of the production processes of the enterprise is being slowly implemented, without expanding production facilities. At the same time, the company No. 1 proclaims to have a task to conform to the modern requirements for the technical development of certain sections of the production through the introduction of new equipment and technology, mechanization and automation of the production processes. There are virtually no examples of modernization and replacement of obsolete and worn-out equipment with the new, more productive one at the vast majority of the plants of the enterprise No. 1. 
The organizational structure of the enterprise includes the units, which are responsible for the introduction of innovations, but the share of the production of these units is relatively small in total volume of production. Practically, at the moment, the company has implemented only one project, claiming to be of high technology. However, the project deadlines have been extended several times, which also gives evidence of the difficulties with the introduction of innovations.

For a long time, the company No. 1 has had a severe shortage of funding due to a high debt load in the form of loans taken out for business support and in order to reinforce operating assets, rather than to modernize production.

There is a negative trend in revenues and operational costs, as well as in financial and production indicators in comparison with the average values. It can be stated that the modernization carried out at the company No. 1 is fragmented.

Characteristic of the industrial enterprise No. 2.

The company is actively developing the use of modern materials and new equipment with varying degrees of novelty. First of all, it is explained by implementation of a strategy of acquisition of new markets (increase of sales in the territory of the Siberian Federal District of Russia), and, secondly, by severization of certification requirements for the company products.

The company No. 2 faces a task to match the severed requirements (in particular, an increase in the warranty period for the products of the company), which create a need to provide an intense introduction of modern technologies aimed at improving the quality of the industrial products.

This task is being solved through a search for new technologies and is associated with the appearance of modern equipment. The activity of the enterprise falls within a number of programs of development of the industrial branch, which include measures of innovative procurement of introduction of scientific research and development activities aimed to improve theoretical foundations and computational methods for enhancing the reliability and durability of the production.

Implementation of the modernization strategy of development of the enterprise is, on the one hand, a requirement of state programs of development of the industrial branch, and on the other hand, it is a choice of the company's management, and awareness of the advantages of the modern technologies.

The company has approved a program of renovation of production, which includes tight time limits of completion of the modernization activities. All this makes it possible to characterize the enterprise No. 2 as a company with an intense level of modernization.

Characteristic of the industrial enterprise No. 3.

The company No. 3 enjoys a status of a research and production association and belongs to knowledgeintensive industries in the Russian Federation. The company's products are diversified. The company produces products both for defense and civil purposes.
Assimilation of new products is one of the priorities of development of the enterprise. When placing orders, great attention is paid to formation of competitive value of the enterprise's products: to a large extent, quality characteristics of the developed products are not inferior to the foreign-made analogues; therefore, the cost for the consumers becomes a key factor in decision-making. Also, the strict terms are set for manufacturing of the first lots of products produced within the tenders won by the enterprise. All this requires high speed and intensification in all structural divisions of the enterprise and the overall high production standards.

The specific requirements for the quality of the products are, in general, related to the implementation of the state defense order of the Russian Federation and to the presence of the system of state military technical reception at the enterprise. The quality management system of the company complies with the specific requirements, and this determines high processability and research intensity of the entire production process.

The enterprise No. 3 has a production base, which is relatively similar to that of the leading Russian and foreign companies. The enterprise cooperates with the Russian Union of Scientific and Engineering Public Organizations and with the Academy of Engineering Sciences of the Russian Federation. The company cooperates with higher educational institutions of the country, which is considered as an important part of the personnel policy of the enterprise, it possesses its own research center, institutionalized in the form of a technology park. The latter is considered as an institutional resource dedicated to the interaction of specialists engaged into innovative activities.

The company No. 3 is following a concept of formation of a team of managers, professionals and executives, which can meet the challenges of innovative development and whose members should have the necessary knowledge and skills allowing them to carry out innovative activities. Therefore, the staff of the enterprise takes part in annual international, sectorial and cross-sectorial exhibitions, conferences, round tables dedicated to new types of products and modern production technology; they systematically attend courses of advanced vocational training in the sphere of their professional expertise and in personnel management.

We can say that this enterprise is in good position for elaboration and development of scientific and technical solutions, it determines directions of innovative business investment, it has a detailed plan to achieve the goals of innovation activities, aimed at strengthening the company's competitiveness, not only nationally, but also internationally.

We can conclude that the level of development of the enterprise No. 3 corresponds to an innovative company.

The summarized results of evaluation of the level of development of the three industrial enterprises of the Ural Federal District based on the characteristics of modernization and innovative development are presented in the Table 1.

This comparative evaluation lets us legitimately characterize the enterprise No. 1 as a company with 
fragmented modernization, the enterprise No. 2 as a company with intensive modernization, and the enterprise No. 3 as an innovative company.

Table 1. Comparative Evaluation of the Level of Development of the Industrial Enterprises Based on the Characteristics of Modernization and Innovative Development.

\begin{tabular}{|c|c|c|c|}
\hline $\begin{array}{c}\text { Compared } \\
\text { characteristic }\end{array}$ & $\begin{array}{c}\text { Enterprise } \\
\text { No. } 1\end{array}$ & $\begin{array}{c}\text { Enterprise } \\
\text { No. } 2\end{array}$ & $\begin{array}{c}\text { Enterprise } \\
\text { No. } 3\end{array}$ \\
\hline $\begin{array}{l}\text { Attitude to their } \\
\text { own research base }\end{array}$ & $\begin{array}{l}\text { Absent and is } \\
\text { not forming }\end{array}$ & $\begin{array}{l}\text { Absent but is } \\
\text { forming }\end{array}$ & $\begin{array}{c}\text { Present and is } \\
\text { being } \\
\text { maintained }\end{array}$ \\
\hline $\begin{array}{l}\text { Orientation } \\
\text { towards } \\
\text { introduction of } \\
\text { innovations }\end{array}$ & $\begin{array}{c}\text { Oriented } \\
\text { towards a partial } \\
\text { replacement of } \\
\text { worn-out } \\
\text { equipment }\end{array}$ & \begin{tabular}{|c|} 
Oriented \\
towards import \\
of technology
\end{tabular} & \begin{tabular}{|c|} 
Oriented \\
towards \\
elaboration of \\
its own high- \\
technology \\
products \\
\end{tabular} \\
\hline $\begin{array}{c}\text { Investment } \\
\text { potential of } \\
\text { introduction of } \\
\text { innovations }\end{array}$ & $\begin{array}{c}\text { Low investment } \\
\text { potential }\end{array}$ & $\begin{array}{c}\text { High investment } \\
\text { potential }\end{array}$ & $\begin{array}{c}\text { World-class } \\
\text { investment } \\
\text { potential }\end{array}$ \\
\hline $\begin{array}{c}\text { Contacts with } \\
\text { scientific and } \\
\text { educational } \\
\text { agencies }\end{array}$ & $\begin{array}{c}\text { Yes, at the level } \\
\text { of staff training } \\
\text { and quality } \\
\text { control }\end{array}$ & $\begin{array}{l}\text { Yes, at the level } \\
\text { of staff training }\end{array}$ & $\begin{array}{c}\text { Yes, at the } \\
\text { level of staff } \\
\text { training, R\&D } \\
\text { conduction } \\
\end{array}$ \\
\hline $\begin{array}{c}\text { Presence of } \\
\text { innovational } \\
\text { structures in the } \\
\text { structure of the } \\
\text { enterprise }\end{array}$ & No & No & $\begin{array}{c}\text { Yes: a } \\
\text { technology } \\
\text { park }\end{array}$ \\
\hline $\begin{array}{c}\text { Conclusion based } \\
\text { on the analysis } \\
\text { results }\end{array}$ & $\begin{array}{c}\text { With } \\
\text { fragmented } \\
\text { modernization }\end{array}$ & $\begin{array}{l}\text { With intensive } \\
\text { modernization }\end{array}$ & $\begin{array}{l}\text { Innovative } \\
\text { enterprise }\end{array}$ \\
\hline
\end{tabular}

Now we would like to construe the results of the empirical research aimed at studying the relationship between managers' leadership style and manifestations of managerial culture at the industrial enterprises (Tables 2 and 3).Mann-Whitney U-test was used to investigate the differences [19-20].

Table 2. Differences in the Manifestation of Transformational Lleadership Style of the Managers of the Industrial Enterprises with Different Modernization and Innovation Processes.

\begin{tabular}{|c|c|c|c|}
\hline \multirow{2}{*}{$\begin{array}{l}\text { Industrial enterprises } \\
\text { (Number of people) }\end{array}$} & \multicolumn{3}{|c|}{ Transformational leadership } \\
\hline & $\begin{array}{l}\text { Rank } \\
\text { sum }\end{array}$ & $\begin{array}{l}\text { Average } \\
\text { number }\end{array}$ & U emp. \\
\hline $\begin{array}{l}\text { Enterprise No. 1: } \\
\text { fragmented } \\
\text { modernization } \\
(80 \text { people })\end{array}$ & 6333,5 & 56,4 & \multirow[t]{2}{*}{3093,5} \\
\hline $\begin{array}{c}\text { Enterprise No. } 2: \\
\text { intensive modernization } \\
(89 \text { people })\end{array}$ & 8031,5 & 58,3 & \\
\hline $\begin{array}{l}\text { Enterprise No. 1: } \\
\text { fragmented } \\
\text { modernization } \\
(80 \text { people })\end{array}$ & 4416,0 & 56,4 & \multirow{2}{*}{$\underset{* *}{1176,0}$} \\
\hline $\begin{array}{c}\text { Enterprise No. 3: } \\
\text { innovative activity } \\
\text { (59 people) }\end{array}$ & 5314,0 & 63,6 & \\
\hline $\begin{array}{c}\text { Enterprise No. } 2: \\
\text { intensive modernization } \\
(89 \text { people })\end{array}$ & 5548,0 & 58,3 & \multirow{2}{*}{$\underset{* *}{1543,0}$} \\
\hline $\begin{array}{c}\text { Enterprise No. } 3: \\
\text { innovative activity } \\
\text { (59 people) }\end{array}$ & 5478,0 & 63,6 & \\
\hline
\end{tabular}

The Table 2 shows that transformational leadership style is more significantly represented by the managers of the enterprises focused on innovative activity, than by the managers of the enterprises oriented towards fragmented modernization, and the managers of the enterprises with intensive modernization level.

The Table 3 shows that the innovative managerial orientation is more evident at the enterprise, focused on innovation activities, and at the enterprise, oriented towards intensive modernization, than at the enterprise with fragmented modernization.

Table 3. Differences in the Manifestation of Managerial Culture at the Industrial Enterprises with Different Modernization and Innovation Processes (Through the Example of Managerial Orientations).

\begin{tabular}{|c|c|c|c|c|c|c|}
\hline \multirow{3}{*}{$\begin{array}{c}\text { Industrial } \\
\text { enterprises } \\
\text { (Number of } \\
\text { people) }\end{array}$} & \multicolumn{6}{|c|}{ Subject-oriented management } \\
\hline & \multicolumn{2}{|c|}{$\begin{array}{l}\text { Innovative } \\
\text { managerial } \\
\text { orientation }\end{array}$} & \multicolumn{2}{|c|}{$\begin{array}{c}\text { Humanizing } \\
\text { managerial } \\
\text { orientation }\end{array}$} & \multicolumn{2}{|c|}{$\begin{array}{l}\text { Democratic } \\
\text { managerial } \\
\text { orientation }\end{array}$} \\
\hline & $\begin{array}{l}\text { Average } \\
\text { number }\end{array}$ & U emp. & $\begin{array}{l}\text { Average } \\
\text { number }\end{array}$ & U emp. & $\begin{array}{l}\text { Average } \\
\text { number }\end{array}$ & U emp. \\
\hline $\begin{array}{c}\text { Enterprise } \\
\text { No. } 1: \\
\text { fragmented } \\
\text { modernization } \\
(80 \text { people }) \\
\end{array}$ & 39,3 & \multirow{2}{*}{$\begin{array}{c}2897,5 \\
*\end{array}$} & 40,0 & \multirow{2}{*}{2996,5} & 42,4 & \multirow{2}{*}{3345,0} \\
\hline $\begin{array}{c}\text { Enterprise } \\
\text { No. } 2: \\
\text { intensive } \\
\text { modernization } \\
\text { (89 people) }\end{array}$ & 41,5 & & 41,5 & & 42,5 & \\
\hline $\begin{array}{c}\text { Enterprise } \\
\text { No. } 1: \\
\text { fragmented } \\
\text { modernization } \\
\text { (80 people) }\end{array}$ & 39,3 & \multirow{2}{*}{$\begin{array}{c}1895,5 \\
*\end{array}$} & 40,0 & \multirow{2}{*}{$\begin{array}{c}1705,5 \\
* *\end{array}$} & 42,4 & \multirow{2}{*}{$\underset{* *}{1591,0}$} \\
\hline $\begin{array}{l}\text { Enterprise } \\
\text { No. } 3: \\
\text { innovative } \\
\text { activity } \\
\text { (59 people) }\end{array}$ & 41,7 & & 42,9 & & 46,2 & \\
\hline $\begin{array}{c}\text { Enterprise } \\
\text { No. } 2: \\
\text { intensive } \\
\text { modernization } \\
\text { (89 people) } \\
\end{array}$ & 41,5 & \multirow{2}{*}{2605,0} & 41,5 & \multirow{2}{*}{2319,5} & 42,5 & \multirow{2}{*}{$\begin{array}{c}1993,5 \\
*\end{array}$} \\
\hline $\begin{array}{l}\text { Enterprise } \\
\text { No. 3: } \\
\text { innovative } \\
\text { activity } \\
\text { (59 people) }\end{array}$ & 41,7 & & 42,9 & & 46,2 & \\
\hline
\end{tabular}

The managerial culture at the industrial enterprise focused on innovation activities is notable for the highest degree of democratic and humanizing managerial orientations.

\section{Conclusions}

The results of the conducted research show that such criteria as an attitude to their own research base, a focus on innovation, an investment potential for introduction of innovations, contacts with research and educational agencies, presence of institutional innovation structures in the corporation structure, allow us to differentiate industrial enterprises according to how their modernization and innovation processes differ. This is proved by the differences in the managers' leadership 
styles, aimed at introducing changes into the managerial organizational culture, which would support such type of managers' leadership.

The profile of a manager of the industrial enterprise, focused on innovations, includes an index of transformational leadership, which demonstrates managers' orientation towards changes through creation of inspirational motivation, intellectual stimulation and individualized consideration.

The managerial culture at the innovative industrial enterprise includes subject-oriented management, which can be democratic, manifested in commitment to a group decision making process; humanizing, which is manifested in an attitude towards the employees as being valuable and important, occasionally, even without taking into account their organizational results.

The managerial culture at the innovative industrial enterprise and the enterprise with intensive modernization includes innovation-oriented management, which means that the managers are aware of the importance of the changes and they are ready to initiate their constant introduction.

The data obtained can be used to carry out selection procedure of managers at innovative industrial enterprises and enterprises with intensive modernization.

The work was supported by Act 211 Government of the Russian Federation, contract № 02.A03.21.0011.

\section{References}

1. N.M. Lebedeva, E.G. Yacin, Forsyth, 3, 16-26 (2009)

2. A.P. Prokhorov, Russian management model (A. Lebedev studio publishing house, 2014)

3. A. Vas, Journal of General Management, 27, 1, 7189 (2001)

4. R.L. Daft, P.G. Lane, The Leadership Experience (Eksmo, 2006)
5. B.M. Bass, B.J. Avolio, Improving Organizational Effectiveness through Transformational Leadership (Thousands Oaks, CA, 1994)

6. B.M. Bass, R.E. Riggio, Transformational Leadership (2005)

7. V.G. Gryazeva-Dobshinskaya, Social psychology of creativity, 200-207 (2007)

8. V.G. Gryazeva-Dobshinskaya, Psychology of innovation management of organization (Publishing house of the SUSU, 2013)

9. V.G. Gryazeva-Dobshinskaya, Y.A. Dmitrieva, Leadership in innovations: manager's activity resources modeling: monograph (Publishing house of the SUSU, 2016)

10. R. Florida, The Rise of the Creative Class. And How It's Transforming Work, Leisure and Everyday Life (Basic Books, 2002)

11. A. Geus, The Living Company: Growth, Learning and Longevity in Business (HBS Press, 1997)

12. Y.D. Krassovsky, Organizational behaviour (UNITI-DANA, 2012)

13. Y.D. Krassovsky, Socio-cultural basis for businessorganization management (UNITI-DANA, 2007)

14. Y.D. Krassovsky, Behaviour management in a company: effects and paradigms: practical manual (INFRA-M, 1997)

15. B.M. Bass, Journal of Leadership \& Organizational Studies, 7, 3, 18-40 (2000)

16. B.J. Avolio, M. Bass, Journal of Occupational and Organizational Psychology, 72, 441-462 (1999)

17. B.M. Bass, P. Steidlmeier, Leadership Quarterly, 10, 181-217 (1999)

18. J.MG. Burns, Transforming Leadership: A New Pursuit of Happiness (Atlantic Monthly Press, 2003)

19. A. Nasledov, SPSS. Computer analysis of psychology and social sciences data (Piter, 2007)

20. E.V. Sidorenko, Methods of mathematical processing in psychology (2004) 